\title{
Well sediments: a medium for geochemical prospecting, an example from the Nisa region, Portugal
}

\author{
S.P. Vriend, M.J. Dekkers, M.A. Janssen and J. Commandeur \\ Department of Geochemistry. Institute of Earth Sciences, Lniversity of L'trecht. Budapestlaan 4. \\ 3584 CD Utrecht, The Netherlands
}

(Received October 6, 1989; revised and accepted June 4, 1990)

\begin{abstract}
Vriend, S.P., Dekkers, M.J.. Janssen, M.A. and Commandeur, J., 1991. Well sediments: a medium for geochemical prospecting, an example from the Nisa region. Portugal. In: A.W. Rose and P.M. Taufen (Editors). Geochemical Exploration 1989. J. Geochem. Explor., 41: 151-167.

The potential of well sediments for geochemical prospection purposes is assessed in the Nisa region (Portugal). The semiarid terrain is less suited for more conventional prospection media. The composition of well sediments is dependant on local geology. Well sediments actively interact with emerging groundwater. These influences are identified and evaluated through statistical methods, including discriminant function analysis and factor analysis. Contamination, which may bias the geochemical landscape, appears to be of minor concern. Known mineralized areas ( $\mathrm{U} . \mathrm{Pb}, \mathrm{Zn}, \mathrm{Ba}$ ) show up as strong anomalies. Additional anomalies of associations of several ore-related elements are attractive targets for foliow-up study. Single-element anomalies may be caused by local pollution. In general. well sedinients, if available, may offer an attractive alternative to more conventional prospecting media in arid and semiarid regions.
\end{abstract}

\section{INTRODUCTION}

Geochemical prospecting for minerals is carried out through sampling of a wide variety of naturally occurring materials (Rose et al., 1979). For reconnaissance type surveys these include streami sediments, stream waters, ground waters, glacial debris, lake sediments and soils. These sample media are often less suited in arid or semiarid regions. Groundwater sampling has been shown to be successful in such areas especiaily for typically mobile elements like $U$ and $\mathrm{F}$ and, more recently, even for $\mathrm{Au}$ (Bergeron and Choinière, 1989). However, this medium is not favorable for the less mobile metals. Their concentrations in solution generally are extremely low which complicates the analytical procedure. Moreover, effects of supersaturation with respect to many minerals - even at these low concentrations - bias the geochemical landscape. 
Recently, a groundwater survey was carried out in the Nisa region, central Portugal (Dekkers et al., 1989) with the prime objective or studying the manifestation of $U$ deposits in these waters. The study area is located between Monte Claro and Povao e Meadas - an area rich in small mineralizations (cf. Fig. 1). A genetic history was established for each water sample on basis of major-element chemistry. Deep, surficial and polluted waters could be discriminated, thus greatly improving the interpretability of the anomaly pattern. However, mineral deposits other than $U$ mineralizations appeared to be poorly reflected in he groundwater composition. A possible alternative prospecting medium, rot mentioned in current literature, is well sediment. The intimate interaction between emerging groundwater and the well sediment may well prove suitable for mineral exploration, owing to a favorable element partitioning between the solution and scavenging sediments.

The present study in the same area between Nisa and Povoa e Meadas (Fig.

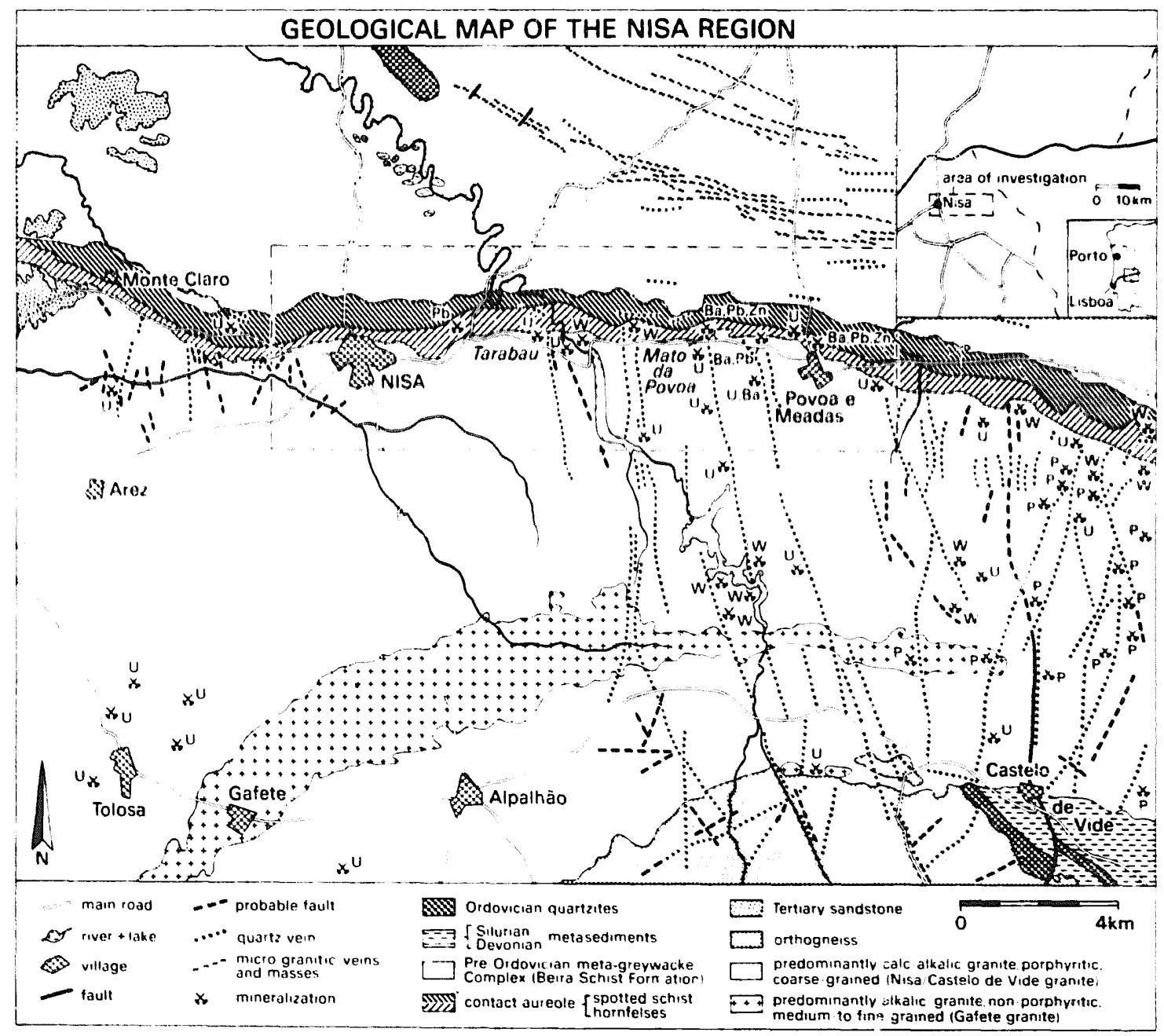

Fig. 1. Geological map of the Nisa region, east-central Portugal, after Ribeiro et al. (1965) and Fernandes et al. (1973). 
1 ) investigates this potential of well sediments in exploration geochemistry. The active interaction with passing groundwater is demonstrated through the impact to bedrock difference, major chemical processes and possible human influences. Statistical techniques are used as a major aid in visualizing geochemical differences and processes. In a final test the anomaly pattern ensuing from the well sediment data is compared to the areal distribution of the known mineralizations.

\section{GEOLOGICAL SETTING}

-

A multiple intrusive complex is located south of Nisa. A Caledonian intrusive body is bordered by two large intrusive bodies of the younger Hercynian granite series: the Nisa/Castelo de Vide (NCdV) and Gafete granites (Fig. 1; Fernandes, 1970, 1971). The Caledonian intrusive was altered into orthogneiss during the Hercynian orogeny. The northernmost coarse-grained, S-type, two-mica NCdV granite (age $\pm 300 \mathrm{Ma}$ ) contains many vein-type mineralizations.

The probably infracambrian Beira Schist Formation (BSF, Thadeu, 1977) with a large areal extent in the western Iberian Peninsuia - forms the northern contact of the NCdV granite complex. In the Nisa region it has undergone low-grade regional metamorphism. Intrusion of the NCdV granite caused a contact-metamorphic overprint; an inner hornfels zone and an outer spotted schist zone are recognized (Fig. 1). Typical mineralogy of the spotted schist zone comprises quartz, feldspars, biotite, white mica, chlorite and cordierite, with accessory graphite and pyrite. The nornfels zone has a similar mineralogy; only chlorite is virtually absent. Garnet and (clino)zoisite occur occasionaliy (Pilar, 1966a,b).

Peneplanation was completed in Tertiary times. The present erosional level has reached the original roof zone of the NCdV granite (Pilar, 1966\%).

\section{MINERALIZATIONS}

The Nisa region is known for its U deposits (Fig. 1). Quartzitic U-bearing veins occur in the NCdV granite, and disseminated $U$ deposits in the contact zone. The disseminated deposits are thought to be extensions of the U-bearing vein systems in the granite. Important ore minerals in both mineralization types are uranyl-phosphates such as autunite, torbernite. Ba-autunite, bassetite, autunite-uranocircite.

Uranium occurrences in the study area are the Tarabau and Mato do Povoa veins (De Faria, 1966). The well-known disseminated Nisa deposits occurs to the west (Pilar, 1966a,b) and the formerly mined Tolosa vein to the south (Ferreira, 1971).

Other mineralizations ( $\mathrm{Ba}, \mathrm{Pb}, \mathrm{Zn}$ and marginally $\mathrm{W}$ ) are also related to 
quartzitic veins in the granite with extensions into the granite/schist contact zone. The veins host (small) occurrences of wolframite, barite, apatite and galena-sphalerite (Neiva et al., 1953; Ribeiro et al., 1965; Fernandes et al., 1973 ). More comprehensive descriptions are given by Dekkers et al. (1984).

The mineralizations were formed under a widely differing hydrothermal regime. High-temperature conditions are represented by wolframite deposits, intermediate-temperature conditions by apatite deposits and low-temperature conditions by barite, uranylphosphate and galena/sphalerite deposits. Age relations between these deposits are not definitely established; in the usually multiple metalliferous veins only relative ages are known (Neiva et al., 1953). However, it is possible that the deposits encompass a wide range of ages from late Hercynian for the high-temperature to late Alpine for the lowtemperature phases. Radiogenic heat could have driven mineralized fluids through vein systems during rejunevation of faults during geologic history (Fehn et al., 1978).

\section{HYDROLOGY AND WELL DESCRIPTION}

The study area is characterized by Mediterranean climate with hot summers and precipitation mainly in winter. The NCdV granite constitutes a virtually flat topographic high. Its contact-metamorphic aureole slopes steeply to the north. The drainage system is poorly developed with very low discharge in summer. During the summer, water supply is chiefly maintained through artificial lakes. Most of the study area is dry and barren almost without soil, or covered with forests (mainly eucalyptus). Horticulture and agriculture (cereals) are concentrated around small towns and viilages.

In former times, wells were commonly excavated for subsistence tarming. Nowadays, many are out of active use, thus diminishing the anthropogenic effect. Generally, the well diameter is some $2 \mathrm{~m}$; well depths range from 2 to $20 \mathrm{~m}$ depending on the local water table. No masonry is used in their construction. Yields are low; in most cases water is manually extracted. More wells are located in the granite than in the schist.

\section{SAMPLING AND SAMPLE PREPARATION}

Sediment samples were collected from the bottom of the wells with a hand credge. Wet sieving to a grain size of $-1.0 \mathrm{~mm}$ was carried out in situ. The samples were sun-dried in Kraft paper bags. A small pilot study, comparing the $100-250 \mu \mathrm{m}$ and the $-63 \mu \mathrm{m}$ fractions, indicated that the $-63 \mu \mathrm{m}$ fraction gave generally a better anomaly-background contrast. Subsequently, all samples were sieved to a grain size of $-63 \mu \mathrm{m}$. 


\section{ANALYTICAL METHODS}

Inductively coupled plasma (ICP) analysis for $\mathrm{K}, \mathrm{Ca}, \mathrm{Mg}, \mathrm{Fe}, \mathrm{P}, \mathrm{S}, \mathrm{Li}, \mathrm{Ti}, \mathrm{Cr}$, $\mathrm{Ba}$

Two hundred and fifty mg of each sample was leached overnight at $90^{\circ} \mathrm{C}$ with $12 \mathrm{~N} \mathrm{HCl}$ and, after cooling, diluted to $250 \mathrm{ml}$ with deionized water. These solutions were then directly analyzed by ICP.

$X$-ray fluorescence (XRF) analysis for $\mathrm{Mn}, \mathrm{Rb}, \mathrm{Sr}, \mathrm{Zr}, \mathrm{Nb}, \mathrm{Ta}, \mathrm{Cu}, \mathrm{Ni}, \mathrm{Co}, \mathrm{Pb}$, $Z n, V, Y, U, W$

Pressed powder tablets were prepared of 8-g sample with $0.75 \mathrm{~g}$ elvacite (Dupont-Nemours) as binder. The tablets were analyzed by XRF using a Philips PW 1400 model. For calibration, pressed powder tablets of international natural rock standards were used.

\section{Organic matter}

An estimate of the organic content of the samples was obtained though determination of the weight loss at $950^{\circ} \mathrm{C}$ after drying the samples at $110^{\circ} \mathrm{C}$. As a control on the quality of this raiher crude approach, the organic content was also determined with the Kelsey method [Walkley, 1935; the method is based on the measurement of the pressure of $\mathrm{CO}_{2}$, produced by heating the sample to $900^{\circ} \mathrm{C}$. The evolved gasses are led over hot $\mathrm{CuO}\left(900^{\circ} \mathrm{C}\right) . \mathrm{H}_{2} \mathrm{O}$ is separated cryogenically. Interference of carbonate $\mathrm{CO}_{2}$ is suppressed through prior treatment of the sample with $\left.\mathrm{HC}_{1}(1: 1)\right]$ in eighteen samples. Agreement between the two methods was satisfactory.

\section{RESULTS AND INTERPRETATION}

If well sediments are indeed suited for prospecting, they must be geochemically active. This implies that geochemical parameters are reflected in their (varying) composition.

\section{Bedrock differences - discriminant function analysis}

Bcdrock differences are reflected in the composition of the well sediments. These show up particularly in the $\mathrm{Cu}, \mathrm{K}, \mathrm{Cr}, \mathrm{Fe}, \mathrm{Mg}, \mathrm{Ni}, \mathrm{Co}$ and $\mathrm{V}$ contents which are higher in the schist well sediments, and in the $\mathrm{Y}, \mathrm{Rb}, \mathrm{U}, \mathrm{Ta}, \mathrm{Nb}$ and $\mathrm{Zr}$ contents which are higher in the granite well sediments (Table 1). These differences (see Fig. 2 for some pronounced examples) are readily explained through the mafic character of the BSF and the acid character of the NCdV 


\section{TABLF I}

Geometric means $(b)$ and geometric means plus and minus one standard deviation ( $s$ : based on the logarithmic values) for the analyzed compounds in granite and schist well sediments ( $\mathrm{rc}$ pectively 46 schist and 61 granite samples). The arithmetic mean and arithmetic mean plus and minus one standard deviation are given for organic matter. All data are in parts per million unless otherwise indicated. Outliers were excluded

\begin{tabular}{|c|c|c|c|c|c|c|}
\hline \multirow[t]{2}{*}{ Compound } & \multicolumn{3}{|l|}{ Schist } & \multicolumn{3}{|l|}{ Granite } \\
\hline & $b$ & $b-s$ & $b+s$ & $b$ & $b-s$ & $b+s$ \\
\hline K $(\%)$ & 0.41 & 0.26 & 0.64 & 0.24 & 0.16 & 0.34 \\
\hline $\mathrm{Ca}$ & 1320 & 720 & 2420 & 1820 & 1020 & 3240 \\
\hline $\mathrm{Mg}$ & 5180 & 3790 & 7080 & 2530 & 1730 & 3700 \\
\hline $\mathrm{Fe}(\%)$ & 3.1 & 1.8 & 5.2 & 1.46 & 0.96 & 2.2 \\
\hline $\mathrm{Mn}$ & 287 & 156 & 530 & 260 & 165 & 400 \\
\hline $\mathrm{P}$ & 915 & 390 & 2180 & 800 & 470 & 1360 \\
\hline$S$ & 1590 & 455 & 5500 & 970 & 420 & 2220 \\
\hline $\mathrm{Ti}$ & 555 & 315 & 980 & 365 & 210 & 645 \\
\hline Org $(\%)$ & 3.7 & 1.9 & 5.4 & 4.8 & 2.6 & 7.0 \\
\hline $\mathrm{Li}$ & 32 & 19 & 52 & 38 & 20 & 72 \\
\hline $\mathrm{Rb}$ & 160 & 110 & 220 & 245 & 180 & 330 \\
\hline $\mathrm{Sr}$ & 43 & 36 & 52 & 44 & 37 & 53 \\
\hline $\mathrm{Ba}$ & 122 & 57 & 261 & 75 & 48 & 118 \\
\hline $\mathrm{Zr}$ & 235 & 175 & 315 & 360 & 220 & 590 \\
\hline $\mathrm{Nb}$ & 9 & 7 & 13 & $1 j$ & 9 & 19 \\
\hline $\mathrm{Ta}$ & 5.0 & 3.5 & 7.8 & 6.5 & 4.7 & 9 \\
\hline $\mathrm{Cr}$ & 46 & 31 & 67 & 13 & 9 & 19 \\
\hline $\mathrm{Ni}$ & 27 & 19 & 39 & 3.6 & 1.9 & 7.0 \\
\hline $\mathrm{Co}$ & 20 & 13 & 30 & 7 & 3.5 & 14 \\
\hline V & 117 & 87 & 157 & 34 & 25 & 48 \\
\hline Cu & 40 & 21 & 74 & 18 & 7 & 42 \\
\hline $\mathrm{Zn}$ & 225 & 115 & 445 & 130 & 80 & 215 \\
\hline $\mathrm{Pb}$ & 49) & 26 & 93 & 38 & 25 & 58 \\
\hline$U$ & 19 & 6 & 58 & 55 & 32 & 92 \\
\hline$Y$ & 9.6 & 6.3 & 14 & 21 & 12 & 37 \\
\hline
\end{tabular}

granite. The high $\mathrm{Mg}$ and $\mathrm{K}$ contents of the spotted schist may be related to ubiquitously occurring cordierite and $\mathrm{K}$ micas.

To test the significance of the difference between well sediments of the granite and schist areas, a discriminant function analysis (DFA) was carried out (SPSS, Nie et al., 1975). Sediments were assigned to either lithology on the basis of field observation. Field classification was impossible for some samples collected in the immediate vicinity of the contact. Prior to the DFA the constituents with lognormal characteristics were log transformed. All constituents were entered into the analysis (direct method). The DFA classification concurs with the field observation for no less than 96 percent of the cases. Hence, differences between granite and schist sediment may be regarded as statistically significant. The few incorrectly classified samples are all close to 

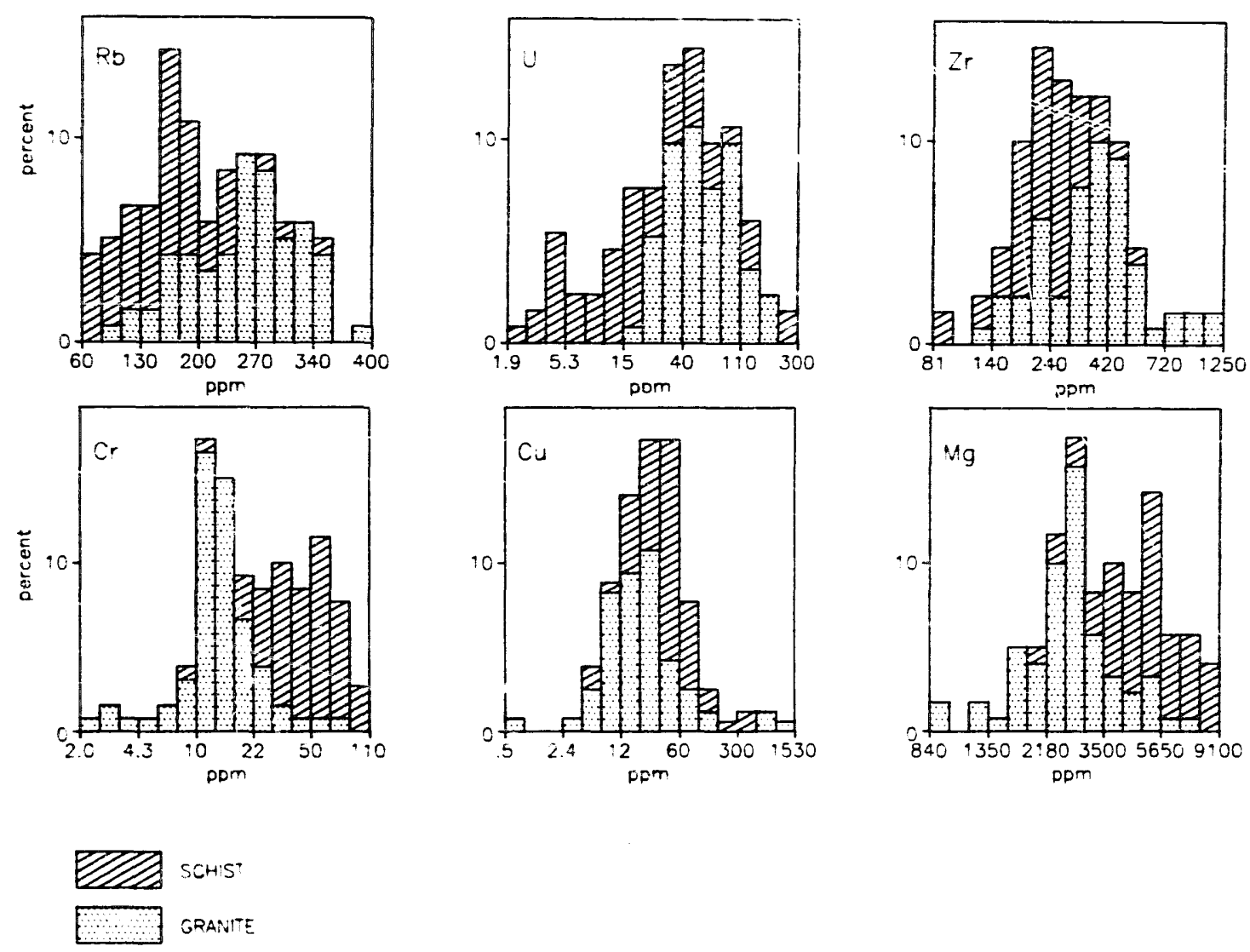

Fig. 2. Histograms of some elements that show contrasting distributions for element concentrations in well sediments derived from different lithologies. Granite sediments are indicated with the dotted parts of the bars and schist waters with the hatched parts.

the contact. For the samples with unknown provenance and these mis-classified samples the DFA classification is used throughout this study.

\section{Geochemical processes - factor analysis}

Important processes in the formation of well sediments within each lithology may be traced in their changing chemical composition. The ensuing correlation patterns are conveniently studied through factor analysis.

Factor analysis was carried out on the granite and schist data sets separately. The procedure to arrive at a final robust model (log transformation if necessary, factoring procedure, removal of multivariate outliers) is described in detail in Vriend et al. (1985) and Dekkers et al. $(1986,1989)$ and will not be reiterated here. The SPSS (Nie et al., 1975) PAl program for principal component analysis combined with Kaiser varimax rotation was used. Parallel factors in the schist $(S)$ and granite $(G)$ groups have been labelled by the same number. For clarity only the higher loadings are mentioned in the text. Full details are found in Table 2. 
TABLE 2

Rotated factor models for the granite and schist sediments

\begin{tabular}{|c|c|c|c|c|c|c|c|}
\hline \multirow[t]{2}{*}{ Compound } & \multicolumn{4}{|c|}{ Schist factor } & \multicolumn{3}{|c|}{ Granite factor } \\
\hline & Sl & S2 & S3 & $\mathrm{S} 4$ & G1 & G2 & G3 \\
\hline Organic & & & 0.65 & & & 0.26 & 0.76 \\
\hline $\mathrm{Cu}$ & 0.47 & -0.51 & 0.32 & & 0.30 & 0.31 & 0.28 \\
\hline $\mathrm{Pb}$ & 0.25 & & 0.42 & & & 0.56 & \\
\hline $\mathrm{Zn}$ & 0.27 & & 0.69 & & & 0.64 & \\
\hline U & & -0.77 & & & & 0.62 & 0.31 \\
\hline $\mathbf{S}$ & -0.27 & & 0.71 & & & & 0.75 \\
\hline Li & & & & 0.44 & 0.87 & & \\
\hline $\mathbf{R b}$ & & -0.36 & -0.31 & 0.74 & 0.39 & & -0.80 \\
\hline $\mathrm{K}$ & 0.80 & & & & 0.86 & & \\
\hline $\mathbf{P}$ & & 0.33 & 0.44 & 0.65 & 0.29 & 0.79 & \\
\hline $\mathrm{Ca}$ & & & 0.52 & 0.51 & & 0.55 & \\
\hline $\mathrm{Sr}$ & 0.62 & & & 0.46 & & 0.33 & -0.74 \\
\hline $\mathrm{Ba}$ & 0.64 & -0.26 & & 0.27 & 0.42 & $0.6 !$ & \\
\hline $\mathrm{Zr}$ & & -0.42 & -0.43 & & -0.27 & & -0.66 \\
\hline $\mathrm{Nb}$ & & -0.40 & -0.60 & 0.51 & & & -0.86 \\
\hline $\mathrm{Ta}$ & & & -0.48 & & & & -0.50 \\
\hline $\mathrm{Mg}$ & 0.77 & 0.38 & & & 0.57 & 0.61 & \\
\hline $\mathrm{Fe}$ & . & 0.77 & 0.36 & & 0.52 & 0.70 & \\
\hline Mn & & 0.77 & & 0.36 & & 0.65 & -0.42 \\
\hline $\mathrm{Ti}$ & 0.54 & & & & 0.86 & & \\
\hline $\mathrm{Cr}$ & 0.83 & & & & 0.73 & 0.34 & \\
\hline $\mathrm{Ni}$ & 0.75 & & & -0.29 & 0.34 & 0.62 & \\
\hline Co & & 0.60 & 0.40 & & & 0.83 & \\
\hline V & 0.74 & 0.34 & -0.30 & & 0.54 & 0.43 & -0.36 \\
\hline $\mathrm{Y}$ & & -0.76 & & & & 0.51 & 0.36 \\
\hline
\end{tabular}

Only loadings and correlations outside the range of +0.25 and -0.25 are giver. The Eigenvalues of the components prior to rotation and respectively for the granite sediments 7.4.4.8, 2.8; for the schist 5.5. 4.3.3.5 and 2.0. All compounds except organic matter were log transformed in the factor analysis.

\section{Schist}

For the samples from the schist terrane of four-factor model was selected.

Factor S1: Clay mineral-mica factor, positive loadings for $\mathrm{Cr}, \mathrm{K}, \mathrm{Mg}, \mathrm{Ni}$, $\mathrm{V}, \mathrm{Ba}, \mathrm{Sr}$ and $\mathrm{Ti}$. This factor points towards weathering processes in the schist and reflects a clay mineral and mica association. The highly loading trace elements are common trace constituents in these minerals.

Facior S2: Fe-Mn coprecipitation factor, positive loadings for $\mathrm{Fe}, \mathrm{Mn}, \mathrm{Co}$ and negative ones for $U$ and $Y$. The element association expected in this factor would be elements coprecipitating and absorbing on Fe and Mn(oxyhydr )oxides that form from waters than turn oxic upon surfacing. These fresh (partly amorphous) hydroxides are very efficient in scavenging other ions (e.g., Whitney, 1975; Nowlan, 1976). An association with many metals would therefore be foreseen. However, only a relatively strong relation with $\mathrm{C}_{\tilde{0}}$ is 
observed. Many trace elements load on the organic matter factor (S3). Organic matter also creates favorable conditions for complexing and immobilization of trace elements (e.g., Govett, 1960). it probably has a greater influence on the trace-element behavior than Fe-Mn (hydr)oxides.

The negative loading of $U$ and $Y$ on this factor is somewhat enigmatic. This aberrant behavior may be explained by gradients generated by the granite: concentrations of $U$ and $Y$ fall with increasing distance to the granite (cf. Fig. 3 ). However, a concurrent increase of $\mathrm{Fe}$ and $\mathrm{Mn}$ with decreasing metamorphic grade was not observed.

Factor S3: Organic matter factor, positive loadings for $\mathrm{S}, \mathrm{Zn}$ and organic matter and a negative one for $\mathrm{Nb}$. The positive loading for organic matter, $\mathrm{S}$ and moderately to weakly for some chalcophile elements $(\mathrm{Zn}, \mathrm{Cu}, \mathrm{Pb})$ versus the negative one for $\mathrm{Nb}$ and weakly negative for some other lithophile elements $(\mathrm{Rb}, \mathrm{Zr}$ and $\mathrm{Ta})$ is ascribed to the fact that high organic content precludes high contents of silicates and related elements and vice versa (an expression of the 'closure effect', see Aitchison, 1986). The chalcophile elements have a rather strong expression in the schist area, possibly related to minor pyrite.

Factor S4: Granitophile element factor, positive loadings for $\mathrm{Rb}$ and $\mathrm{P}$. Samples with high scores on this factor are confined to the immediate vicinity of the contact zone. The granite dips away under the schist and therefore these samples may reflect the proximity of the granite-schist contact.

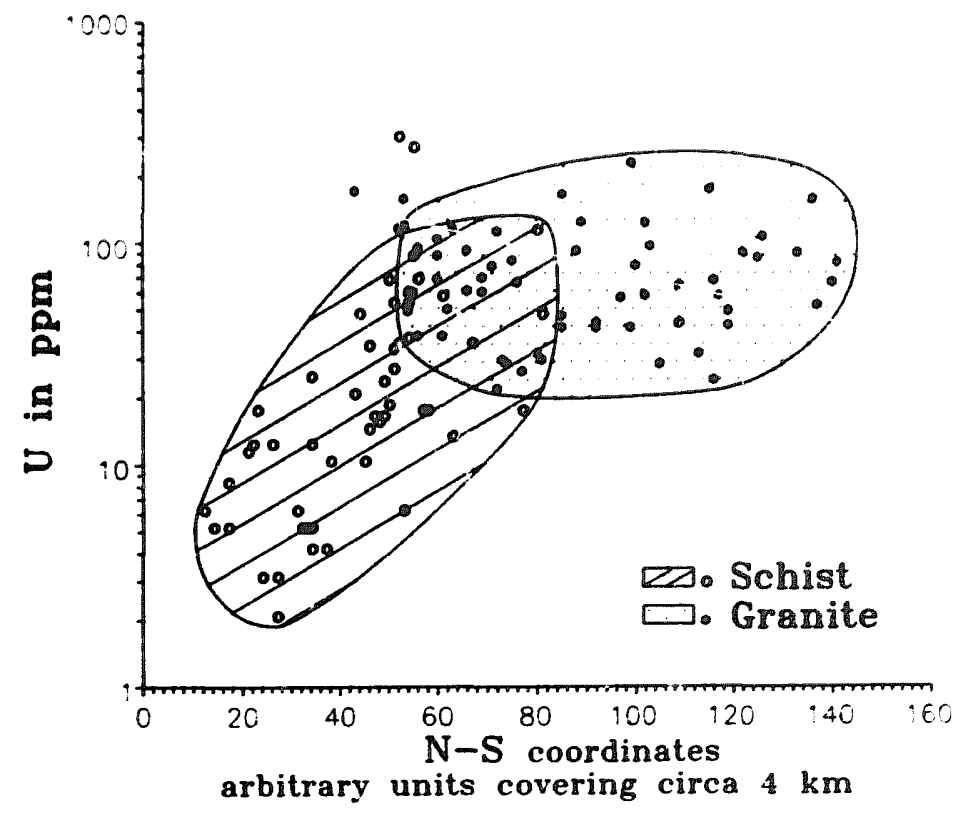

Fig. 3. Scattergram of $U$ concentration versus the $N-S$ coordinate. Note the strong increase in $U$ in the schist well sediments with decreasing distance to the granite. The granite weil sediments do not show a similar trend. 


\section{Granite}

A three-factor mode! was selected for the well sediments from the granite area (Table 2). As is to be expected, a factor expressing a concentration gradient toward the granite like factor $\mathrm{S} 4$, does not show up in the granite sediments themselves.

Factor G1: Clay mineral-mica factor, high positive loadings for $\mathrm{Li}, \mathrm{K}, \mathrm{Ti}$, $\mathrm{Cr}, \mathrm{Mg}$. This factor reflects very similar phenomena as factor $\mathrm{S} 1$ for the schist group. Obviously, the different mica composition in the granite in comparison to the schist causes a difference in element loadings.

Factor G2: Fe-Mn coprecipitation factor, high positive loadings for $\mathrm{Co}, \mathrm{P}$, $\mathrm{Fe}, \mathrm{Mn}, \mathrm{Zn}, \mathrm{Ni}, \mathrm{U}, \mathrm{Ba}, \mathrm{Pb}$ and $\mathrm{Ca}$. The trace elements coprecipitate with $\mathrm{Fe}$ and $\mathrm{Mn}$ (hydr) oxides upon oxygenating of the groundwater. While in the schist sediments this element association is mainly found under the organic matter factor, the balance has tipped over to the Fe-Mn coprecipitation factor in the granite sediments, perhaps due to diverse expression of oxidation phenomena in the different lithologies. In the granite sediments, $\mathrm{P}$ has also a high loading on this factor. Like the trace elements, phosphate is known to be adsorbed onto goethite-like phases (e.g., Atkinson et al., 1974).

Factor G3: Rock debris-organic matter dipole factor, high positive loadings for organic matter and $\mathrm{S}$ and negative ones for $\mathrm{Nb}, \mathrm{Rb}, \mathrm{Sr}$ and $\mathrm{Zr}$. This factor resembles factor S3 of the schist. Due to the lesser expression of the chalcophile elements the antipodal character of this factor is slightly enhanced with respect to that in the schist group.

The relations observed in the factors can be explained by common geochemical phenomena and processes. Moreover, the soundness of the models is supported by the fact that both lithologies, although chemically quite distinct, broadly do yield similar factor models. Factors that should express distinct geographical trends, actually do yield such trends: schist samples with high scores on granite-related factors (S2 and S4) are indeed located close to the contact.

Two types of oxidation-reduction phenomena are thus discerned. Firstly, through a $\mathrm{Fe}$ (hydr) oxide precipitation upon oxygenation of emerging reducing water in oxic sediment. $\mathrm{Fe}^{2+}$ converts to $\mathrm{Fe}^{3+}$ which precipitates as $\mathrm{Fe}$ (hydr)oxide. Such processes can presumably also occur in the absence of abundant organic matter, so that rock interaction plays a more importani role. Secondly, in the presence of decomposing organic matter sediments readily use up their oxygen and reducing conditions result. In stch environments sulphate, when present, is reduced to sulphide mediated through bacteria (odor of $\mathrm{H}_{2} \mathrm{~S}$ ).

The strong association of $\mathrm{Fe}$ and $\mathrm{P}$ and the favorable geochemical erivironment (Nriagu and Dell, 1974) in the granite sediments led us to suspect the presence of vivianite $\left(\mathrm{Fe}_{3}\left(\mathrm{PO}_{4}\right)_{2} \cdot 8 \mathrm{H}_{2} \mathrm{O}\right)$ in those samples with high scores 
on the G2 factor. XRD examination of two of these high-scoring well sediments did prove the presence of this mineral.

The behavior of $U$ and $Y$ in the well sediments is most interesting. They form a concentration plateau in the granite terrane while their concentration slopes down in the schist terrane with increasing distance to the granite (Fig. 3 ). If this present-day behavior may be linked to the ore-forming process, this could point to a metasomatic process whereby $U$ (and $Y$ ) was transferred from the granite and trapped by changing chemical (redox?) conditions in the schist contact zone. This feature shows certain parallels with the observed vein-type $U$ deposits in the granite and disseminated deposits in the schist contact zone.

\section{Human impact}

Factor models did not hint at any pollution-like process. Thus, it is reasonable to conclude that human impact, if present, is only marginal. This is corroborated by the fact that high values of pollution-sensitive elements (like $\mathrm{Pb}$ and $\mathrm{Zn}$ ) mostly coincide with high values for other common ore-paragenetic $(\mathrm{Ba}, \mathrm{Cu}, \mathrm{U})$, favoring a natural origin. Nonetheless, since local pollution effects can not be totally excluded, single-element anomalies should be regarded with caution and assigned a low prospection priority. In the next section the value of anomalies is evaluated through its ore-element association.

\section{Anomaly evaluation}

In particular $\mathrm{U}, \mathrm{Pb}, \mathrm{Zn}, \mathrm{Ba}$ mineralizations occur in the study area; therefore these elements are most interesting to evaluate the potential of well sediments for geochemical exploration. Study of the histograms of the ore-related elements already revealed the presence of anomalous values, and especially showed conspicuous highs for $\mathrm{Pb}$.

In order to rectify the influence of differences in lithology on the background and threshold values, the following procedure was adopted, thereby avoiding the use of more than one threshold value per element and per map (Fig. 4):

- Determination of the means and standard deviations in the distributions (logtransformation was applied if necessary) for the background populations of the separate lithologies with the help of cumulative frequency curves (Sinclair. 1976). Outlying parts of the distribution, expressed by breakpoints or inflection points in the cumulative frequency curve, were split off prior to the determination of these values.

- Standardization of the data per element and per lithology to a mean value of 0.0 and to a standard deviation of 1.0 .

- Construction of cumulative frequency curves for the combined standard- 


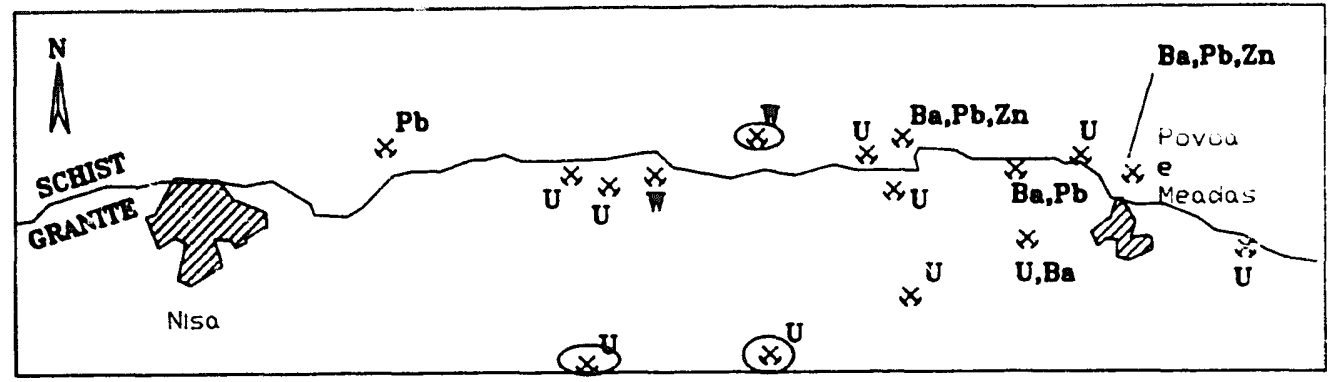

$\frac{1}{2 \mathrm{~km}} \otimes$ no sampling within drainage pattern of mineralization
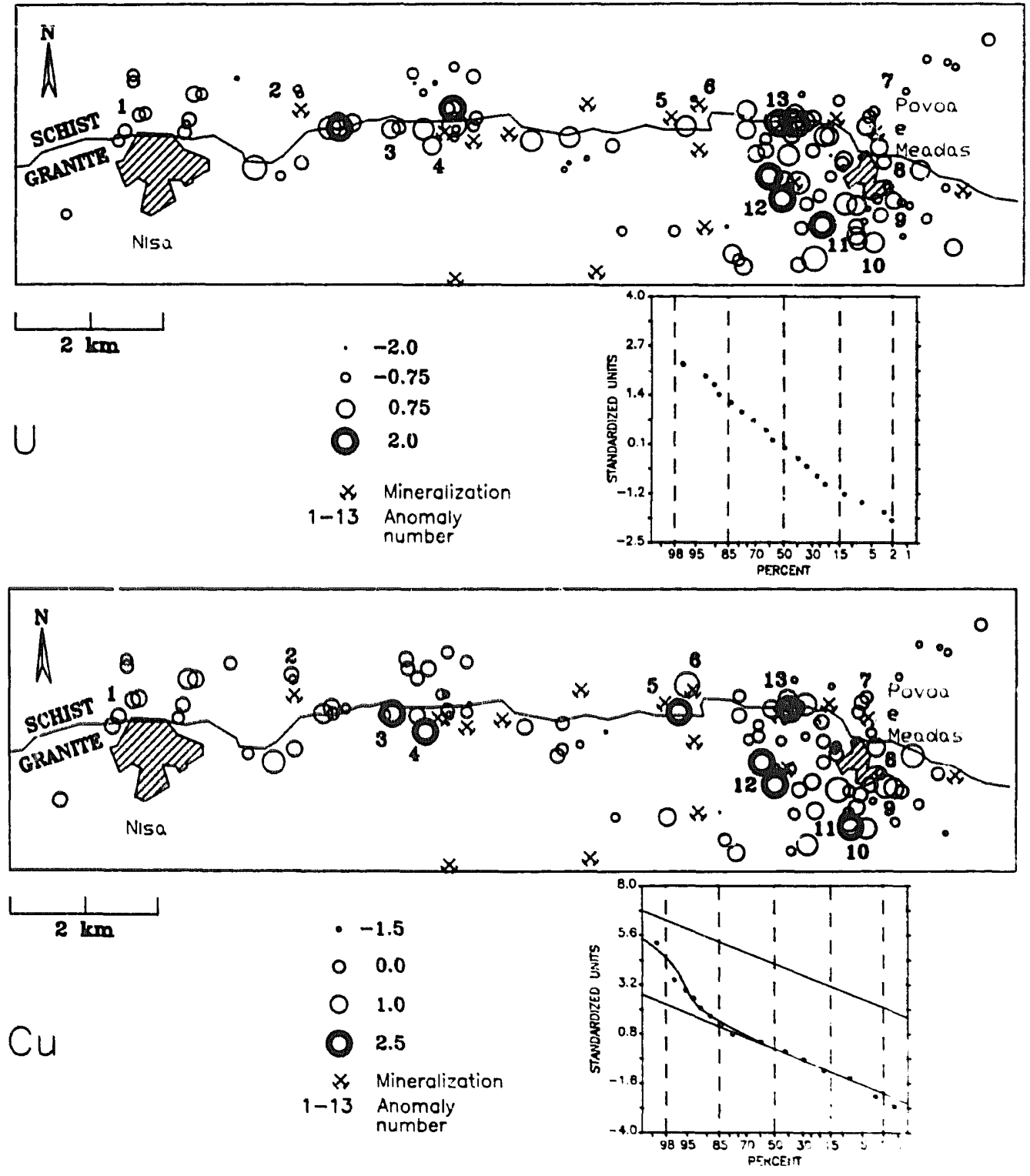

Fig. 4. Anomaly patterns and mineralizations for $\mathrm{U}, \mathrm{Cu}, \mathrm{Ba}, \mathrm{Pb}$ and $\mathrm{Zn}$. For each element the cumulative frequency curves are given that were used to determine the threshold value. Data for granite and schist well sediments were standardized separately and then joined for the construction of the curve. The diameter of the circles changes linearly with the standardized concentration in the maps; for reference purposes some circle sizes are labelled with their appropriate standardized units in the keys. The interpretation of each anomaly is listed in Table 3. 

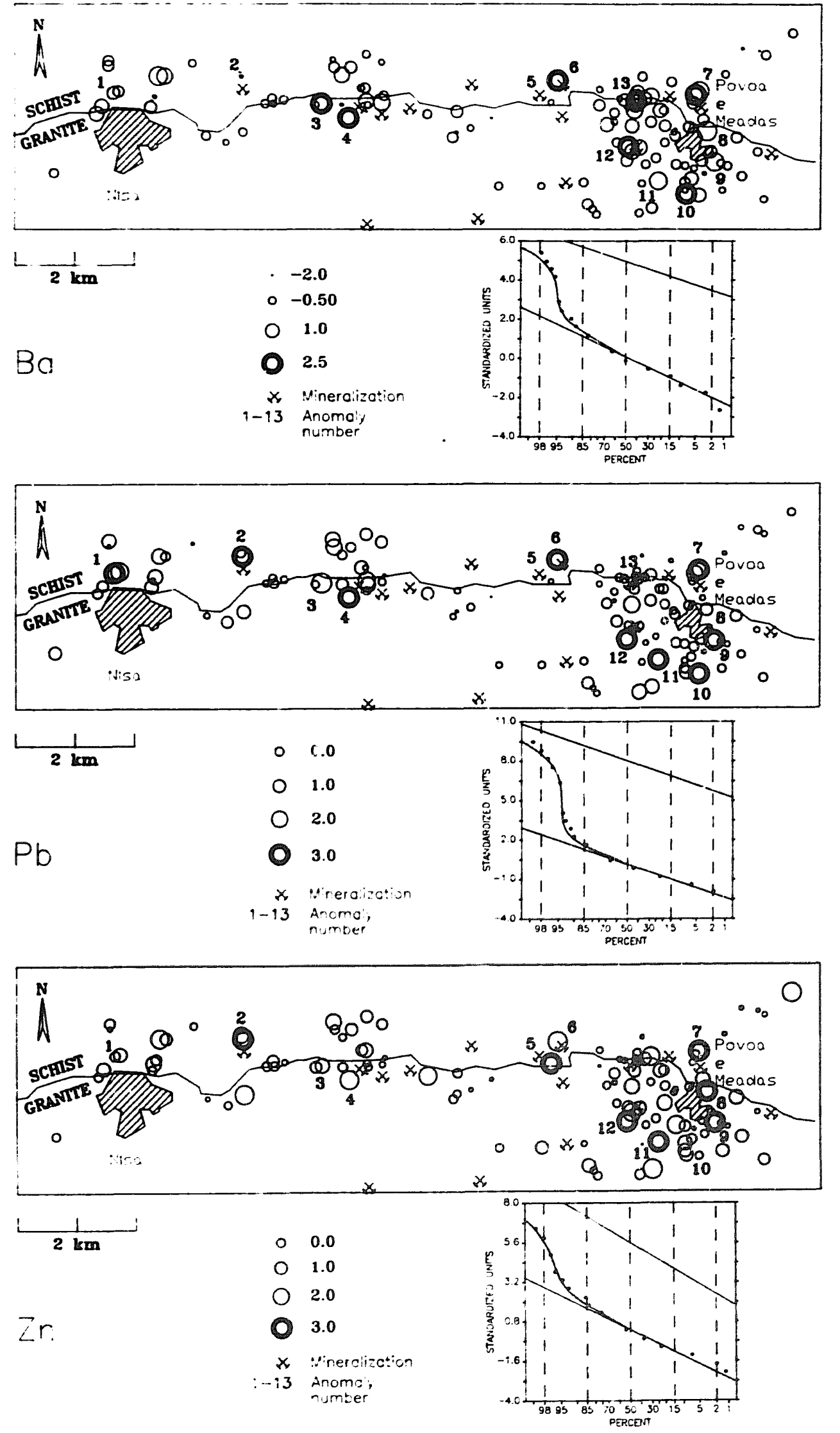
ized data sets of both lithologies and determination of the threshold value for each element.

In the above procedure extensive use was made of the program PROBPLOT (Stanley, 1987).

Only $U$ did not show a clear inflection point in the cumulative frequency curve (Fig. 4). Therefore, somewhat arbitrarily a (in these situations commonly used) value of the mean plus two standard deviations was defined as threshold (Hoffman, 1988). All U anomalies identified through the ground water survey (Dekkers et al., 1989) were also identified in the well sediments (Fig. 4), provided that sampling in the vicinity was possible (a number of water anomalies were found through spring sampling and thus no sediment could be collected in such cases ).

All known $\mathrm{P}$. $\mathrm{Zn}$ and $\mathrm{Ba}$ mineralizations are reflected in the anomaly pattern of the well . ediments. This congruence demonstrates the merit of well sediment sampling for prospection purposes. A pollution explanation seems likely for some single-element $\mathrm{Pb}$ and $\mathrm{Zn}$ anomalies (cf. Table 3 and Fig. 4). The significance of the additional anomalies of associations of several orerelated elements may be evaluated in a follow-up study.

The background-anomaly differences are raiher large for all elements of interest, except for $U$ which shows a more gradual background-anomaly pattern. This smoothing of the anomalous population may be due to the solubility of $U$ in oxidizing water.

Only two W mineralizations of no economic interest occur in the study

TABLE:

Anomaly characterization for $\mathrm{Pb}, \mathrm{Zn}, \mathrm{Cu}$ and $\mathrm{Ba}$

\begin{tabular}{lll}
\hline Number & $\begin{array}{l}\text { Element } \\
\text { association }\end{array}$ & (possible) cause \\
\hline 1 & $\mathrm{~Pb}$ & contamination \\
2 & $\mathrm{mb}, \mathrm{Zn}$ & mineralization $(\mathrm{Pb})$ \\
3 & $\mathrm{Ba}, \mathrm{Cu},(\mathrm{Pb})$ & follow-up \\
4 & $\mathrm{~Pb}, \mathrm{Ba}, \mathrm{Cu},(\mathrm{Zn})$ & mineralization (U) \\
5 & $\mathrm{Cu}, \mathrm{Zn}$ & mineralization $(\mathrm{U})$ \\
6 & $\mathrm{~Pb}, \mathrm{Ba},(\mathrm{Zn}, \mathrm{Cu})$ & mineralization $(\mathrm{Ba}, \mathrm{Pb}, \mathrm{Zn})$ \\
7 & $\mathrm{~Pb}, \mathrm{Zn}, \mathrm{Ba}$ & contamination? \\
8 & $\mathrm{Zn}, \mathrm{Bb}, \mathrm{Zn})$ \\
9 & $\mathrm{~Pb}, \mathrm{Zn},(\mathrm{Ba}, \mathrm{Cu})$ & follow-up \\
$10(2$ wells) & $\mathrm{Pb}, \mathrm{Zn},(\mathrm{Ba}, \mathrm{Cu})$ & follow-up \\
11 & $\mathrm{~Pb}, \mathrm{Zn},(\mathrm{Ba})$ & follow-up \\
$12(3$ wells $)$ & $\mathrm{Pb}, \mathrm{Zn}, \mathrm{Cu},(\mathrm{Ba})$ & mineralization $(\mathrm{U}, \mathrm{Ba})$ \\
13 & $\mathrm{Cu}, \mathrm{Ba}$ & mineralization $(\mathrm{Ba}, \mathrm{Pb})$ \\
\hline
\end{tabular}

Numbers correspond with those in Fig. 4. Elements between brackets have concentrations that fall very close to the threshold. Follow-up implies an attrartive element association warranting more detailed work. 
area. One has no well in its drainage. The other yielded a high $W$ value. Tungsten was not considered in more detail.

\section{DISCUSSION AND CONCLUSIONS}

An explanation for the strong response of ore deposits in the Nisa well sediment composition may well lie in the fact that places that are most favorable to find water close to the surface are also the most favorable to find mineralization. Water in semiarid crystalline areas is most likely to be found in joint and fracture zones. Quartz veins are found frequently in these zones in the Nisa area. It is not uncommon to find springs originating in these veins. Quartz, a brittle mineral, poses in fractured veins little obstruction for water. Hydrothermal mineralizations are generally confined to these environments. These environments are also easiest for the rural population to excavate their wells in. In fact through this "natural selection" barren ground has for a large part already been eliminated from sampling. The well sediments contain clays, Fe-Mn (hydr)oxides and organic material, all phases that are very efficient in immobilizing solved or suspended trace elements. They thus have all characteristics required for a excellent prospecting medium.

Well sediments are an interesting alternative in regions where more conventional prospecting media are less successful. In the Nisa region virtually all known mineralizations are reflected in the well sediment samples, mostly as strong anomalies. Their zone of influence may reach deeper than stream waters and sediments or soils. Concentration levels are such that they can routinely be analyzed with presently available equipment. Factor analysis did not show the presence of any pollution-like process, thus anthropogenic influences are probably minor. Oxidation/reduction processes lead to precipitation of Fe-Mn hydroxides and phosphates which will scavenge trace elements, together with organic matter and clay minerals, from emerging groundwater. This greatly enhances the prospective potential of well sediments.

\section{ACKNOWLEDGEMENTS}

A. Borges de Campos introduced us to the geology of the study area. C.G. Walen assisted in the initial phases of this study. P.F.M. van Gaans and L. Linnartz critically reviewed the manuscript. R.D. Schuiling is thanked for the XRD identification of the phosphate minerals in the well sediments.

\section{REFERENCES}

Aitchison. J.. 1986. The Statistical Analysis of Compositional Data. Chapman and Hall. London. $416 \mathrm{pp}$. 
Atki son, R.J., Parfitt, R.L. and Smart, R.S.C., 1974. Infrared study of phosphate adsorption on goethite. J. Chem. Soc. Faraday Trans. I, 70: 1472-1479.

Bergeron. M. and Choinière, J., 1989. L'or dans les eaux soutcrraines: implications pour l'exploration. J. Geochem. Explor., 31: 319-328.

De Faria, F.L., 1966. Gites d'uranium portligais dans les formations metasedimentaires. Port. Serv. Geol. Comun., 50: 9-50.

Dekkers, M.J., Vriend, S.P., Walen, C.G. and Van Der Weijden, C.H., 1984. Geochemical controls of transport and deposition of uranium from solution, case study Nisa (Portugal). Publ. Inst. Earth Sci., Univ. of Utrecht, contract 007.79.3 EXU NL, 90 pp.

Dekkers, M.J., Vriend, S.P., Van Der Weijden, C.H. and Van Diest, Ph., 1986. The Saõ Pedro do Sul Granite, Portugal: hydrogeochemistry related to the prospection of uranium. Uranium, 2: 261-277.

Dekkers, M.J., Vriend, S.P., Van Der Weijden, C.H. and Van Gaans, P.F.M., 1989. Uranium anomaly evaluation in groundwater: a hydrogeochemical study in the Nisa region, Portugal. Appl. Geochem., 4: 375-394.

Fehn, U., Cathles, L.M. and Holland, H.D., 1978. Hydrothermal convection and uranium deposits in abnormally radioactive plutons. Econ. Geol., 73: $1556-1566$.

Fernandes, A.P., 1970. Contribucao para o estudo da regiao dos granitos radioactivos de S. Pedro do Sul. Junta de Energia Nuclear, Lisboa, $45 \mathrm{pp}$.

Fernandes, A.P., 1971. A geologia da provincia uranifera do Alto Alentego. Contribution :o the economic geological congress Hispano-Luso-Americano, Madrid and Lishon, Sept. 19-25. $1971,13 \mathrm{pp}$.

Fernandes, A.P., Perdigao, J.C., De Carvalho, H. and Peres, A.M., 1973. Carta geologica de Portugal. Escala 1:50.000, noticia explicativa da folha 28D. Castelo de Vide.

Ferreira, P.V., 1971. Jazigos uraniferos portugueses; jazigos de Au-Ag-sulfuretos do Norte de Portugal. Excursion guide book Vol. 5, economic geological congress Hispano-Luso-Americano. Madrid and Lisbon. Sept. 19-25, 1971.

Govett. G.J.S., 1960. Geochemical prospecting for $\mathrm{Cu}$ in Rhodesia. Proc. 2 Ist Int. Geol. Cong.. Copenhagen 1960, Pt. II: 44-56.

Hoffman. S.J.. 1988. Notes from the Editor. Explore, 3: 2-3.

Neiva, J.M.C.. De Queiroz, N.M. and De Faria. F.L.. 1953. Geologie et genese des gisements portugais d'apatite. Int. Geol. Congr. 19th, Algeria. C.R., 11, (11): 145-159.

Nic. N.H., Hull. C.H., Jenking, J.G.. Steinbrenner, K. and Bent. D.H.. 1975. Statistical Package for the Social Sciences. McGraw-Hill Inc., New York, NY, 2nd ed., 675 pp.

Nowlan, G.A., 1976. Concretionary managanese-iron oxides in streams and their usefulness as a sample medium for geochemical prospecting. J. Geochem. Explor., 6: 193-210.

Nriagu. J O. and Dell, C.I. 1974. Diagenetic formations of iron phosphates in recent lake sediments. Am. Mineral., 59: 934-946.

Pilar, L., 1966a. Condicoes de formacao do jazigo uranifero de Nisa. Port. Serv. Geol. Comun.. 50: 51-83.

Pilar, L., 1966b. Petrografia das rochas metamorphicas e dos granitos de contacto da regiao de Nisa. Port. Serv. Geol. Comun., 50: 85-107.

Ribeiro, O., Teixeira, C., De Carvalho, H., Peres, A.M. and Fernandes, A.P., 1965. Carta geologica de Portugal. Escala $1: 50.000$; noticia explicativa sa folha 28B: Nisa.

Rose, A.W., Hawkes, H.E. and Webb, J.S., 1979. Geochemistry in Mineral Exploration. Academic Press, London, $657 \mathrm{pp}$.

Sinclair, A.J., 19:6. Applications of probability graphs in mineral exploration. Assoc. Explor. Geochem., Spec. Vol. 4, 35 pp.

Stanley, C.R., 1987. PROBPLOT. An interactive computer program to fit mixtures of normal (or log-normal) distributions with maximum likelihood optimization procedures. Assoc. Explor. Gieochem., Spec. Vol. 14, 40 pp. 
Thadeu, D.C., 1977. Hercynian paragenetic units of the Portuguese part of the Hesperic massif. Bol. Soc. Geol. Port., 20: 247-276.

Vriend, S.P., Oosterom, M.G., Bussink, R.W. and Jansen, J.B.H., 1985. Trace-element behavior in the W-Sn granite of Regoufe, Portugal. J. Geochem. Explor., 23: 13-25.

Walkley, A., 1935. An examination of methods for determination of organic carbon and nitrogen. J. Agric. Sci., 25: 598-609.

Whitney, Ph.R., 1975. Relationship of manganese-iron oxides and associated heavy metals to grain size in stream sediments. J. Geochem. Explor., 4: 251-263. 